\title{
Biosynthesis and Characterization of Silver Nanoparticles produced by Phormidium ambiguum and Desertifilum tharense
}

\section{Amira Lotfy Hanna ( $\sim$ amira.lotfy.hanna@post.agr.cu.edu.eg )}

National Organization for Drug Control and Research https://orcid.org/0000-0003-3983-1234

Hayam Hamouda

National Organization for Drug Control and Research Agouza Branch: National Organization for Drug Control and Research

\section{Hanan Goda}

Cairo University

\section{Tarek Elsayed}

Cairo University

Mahmoud Sadik

Cairo University

\section{Research Article}

Keywords: Phormidium ambiguum, Desertifilum tharense, Ag-NPs, biosynthesis, characterization, antibacterial, antioxidant

Posted Date: June 25th, 2021

DOI: https://doi.org/10.21203/rs.3.rs-622253/v1

License: (c) (i) This work is licensed under a Creative Commons Attribution 4.0 International License. Read Full License 


\title{
Biosynthesis and Characterization of Silver Nanoparticles produced by Phormidium ambiguum and Desertifilum tharense
}

\author{
Amira L. Hanna ${ }^{\mathrm{a}, *}$, Hayam M. Hamouda ${ }^{\mathrm{a}}$, Hanan A. Goda ${ }^{\mathrm{b}}$, Tarek R. Elsayed ${ }^{\mathrm{b}}$, Mahmoud W. Sadik \\ a Microbiology Department, Division of Basic Medical Science, Egyptian Drug Authority (EDA), \\ National Organization for Drug Control and Research (NODCAR), 12553, Giza, Egypt \\ ${ }^{\mathrm{b}}$ Department of Microbiology, Faculty of Agriculture, Cairo University, 12613, Giza, Egypt \\ *Corresponding Author: Mrs. Amira L. Hanna. Email*: amira.lotfy.hanna@ post.agr.cu.edu.eg.
}

\begin{abstract}
The world faces a challenge with pervasion of multidrug resistant bacteria which encouraged the scientists to develop and discover alternative ecofriendly and easy to produce new antibacterial agents. Two Egyptian cyanobacteria were isolated and identified according to $16 \mathrm{~S}$ rRNA gene sequencing as Phormidium ambiguum and Desertifilum tharense. The sequences were deposited in the GenBank with accession numbers of MW762709 and MW762710 for Desertifilum tharense and Phormidium ambiguum, respectively. These isolates have the ability to produce silver nanoparticles (Ag-NPs) extra- and intracellularly under light and dark conditions. The results of UV-Vis analysis showed promising extracellular Ag-NPs synthesis by Desertifilum tharense and Phormidium ambiguum under light conditions. Therefore, these Ag-NPs were characterized and evaluated for antibacterial and antioxidant activity. TEM, SEM and XRD analyses revealed the spherical crystals with face-centered cubic structures and size range of 6.24-11.4 nm and 6.46-12.2 nm for Ag-NPs of Desertifilum tharense and Phormidium ambiguum, respectively. XRD and EDX results clearly confirmed the successful synthesis of Ag-NPs in its oxide form or chloride form. The FTIR spectrum data confirmed the presence of hydroxyl and amide groups. Desertifilum tharense Ag-NPs displayed the largest inhibition zone ranged from $9 \mathrm{~mm}$ against Micrococcus luteus ATCC 10240 to $25 \mathrm{~mm}$ against methicillin resistant S. aureus (MRSA) ATCC 43300. For Phormidium ambiguum Ag-NPs, the inhibition zone diameter was in a range of 9-18 $\mathrm{mm}$. The Ag-NPs of Phormidium ambiguum exhibited the highest scavenging activity of $48.7 \%$ comparing with that of Desertifilum tharense which displayed $43.753 \%$.
\end{abstract}

Keywords: Phormidium ambiguum, Desertifilum tharense, Ag-NPs, biosynthesis, characterization, antibacterial, antioxidant. 


\section{Introduction}

Nanotechnology is a sonorous area of science, engineering, and technology concerning the design and manufacture of materials at the nanoscale. The products of nanotechnology are nanomaterials or nanoparticles (NPs) having dimensions less than 100 $\mathrm{nm}$. Comparing to larger particles, smaller sized nanoparticles exhibit larger surface-tovolume ratio which is an influential feature to improve physical, chemical, and biological properties of the original material. These properties include catalytic reactivity, thermal conductivity, antimicrobial activity, chemical steadiness, etc. According to the effectual crystallographic and physiochemical properties of NPs, the nanoparticles have substantial applications in industrial, medical and biotechnological sectors (Rajeshkumar et al., 2014 and Patel et al., 2015).

Generally, the nanoparticles could be synthesized by applying different chemical and physical methods. The chemical methods include precipitation, solvothermal/hydrothermal and sol - gel methods using different reducing and stabilizing agents. These methods are not eco-friendly as using of solvents, reducing and stabilizing agents leads to release of considerable amounts of hazards and toxic materials as non-biodegradable compounds (Zak et al., 2011 and $\mathrm{Li}$ et al., 2015). In the physical biosynthesis, attrition and pyrolysis are applied to produce oxidized NPs. The physical methods are very expensive and time consuming. The demerits of chemical and physical methods, and integration of NPs in health and industrial products for human utilization confirming the application of natural and safe methods for nanoparticles synthesis. Therefore, the biosynthesis of nanoparticles using different biological sources including plants, bacteria, fungi and algae has great attention. The biological methods are cost effective, non-toxic, pollutant-free and eco-friendly methods (Malhotra et al., 2013, Keskin et al., 2016, Kumar et al., 2018 and Kashyap et al., 2019).

Cyanobacteria or blue-green algae have a greatest scientific attention for nanoparticles production, not only for their high biomass productivity, but also for they have the ability to bioremediate toxic metals altering them to more adjustable forms. Cyanobacteria have the ability to produce different organic (quaternary ammonium compounds, N-halamine compounds, chitosan, etc.) and inorganic metal and metal oxide NPs (as gold, silver, platinum, zinc oxide and copper oxide, aluminium oxide, etc.). The cyanobacterial synthesis of NPs is accomplished extra or intracellularly. The extracellular biosynthesis involves secretion of extracellular substances to mediate through electrostatic interactions or production of extracellular reductase enzymes. Alternatively, the intracellular production of NPs associates with the activity of reductase enzymes and substance exchange processes (Mahdieh et al., 2012).

The physicochemical properties of silver nanoparticles (Ag-NPs) and their use extensively in the medical sector as antimicrobial and anticancer agents are the foremost reasons for considerable attention for their production. The silver nanoparticles display efficient antibacterial activity through multiple mechanisms including formation of free radicals stimulating membrane damage (Ninganagouda et al., 2014), increasing the cell membrane permeability through formation of holes or channels through it (Beyth et al., 2010) and disruption of cell proteins through binding with thiol and amino groups (Choi et al., 2008).

Based on the promising features and applications of silver nanoparticles, the intended objective of present study was screening of some Egyptian cyanobacterial isolates, as model biological system, to synthesize the Ag-NPs. Furthermore, the physical properties and potential applications of Ag-NPs as antibacterial and antioxidant agents were evaluated. 


\section{Materials and Methods}

\subsection{Green earth crust samples collection}

Two natural earth crust samples were collected from Giza Governorate, El-Haraneya near the ring road in locations between longitude of $31^{\circ} 10^{\prime} 15^{\prime \prime}$ and latitude of $29^{\circ} 58^{\prime} 20^{\prime \prime}$ for the first sample, and longitude of $31^{\circ} 9^{\prime} 59^{\prime \prime}$ and latitude of $29^{\circ} 57^{\prime} 57^{\prime \prime}$ for the second sample.

\subsection{Cyanobacteria isolation and purification}

The enrichment culture technique was applied to isolate cyanobacteria, in which $1 \mathrm{gm}$ of each green dispersed earth crust samples were aseptically added to $25 \mathrm{ml}$ of liquid BG-11 medium (Rippka et al., 1979) but inside horizontal falcon tube not inside glass flask. The inoculated medium was incubated under continuous illumination using Philips Fluorescent white lamps, at a relatively low light intensity (400 -500 lux) at $30^{\circ} \mathrm{C}$ for 10 days.

Different methods should be used to obtain cyanobacteria monocultures/pure culture, depending on the type of cyanobacterial: coccoid or filamentous, cell size and the degree of motility. Pure culture is not always possible because cyanobacteria may have such relationships with other microorganisms.

The single filament technique was used to obtain axenic cultures of filamentous cyanobacteria. Whole trichomes or hormogonia will glide on the wall of the tube through few days. This technique was applied through picking these individual migrating trichomes using a Pasteur pipette, and then the individual filament was cleaned with sterile liquid medium in a petri dish. For more purification, the motile filamentous cyanobacteria was dragged inside BG-11 agar medium to allowing them to glid away and remove any attached contaminations as described by Waterbury (2006). Some of the rapidly gliding filamentous can clean themselves of bacterial contaminants within hours of inoculation. Then, the purified isolates were transferred in flasks containing $250 \mathrm{ml}$ of liquid BG-11 ( $\mathrm{pH} 7)$. All pure isolates were maintained under photoautotrophic growth conditions as aforementioned.

\subsection{Morphological characterization of cyanobacteria}

The pure isolates were characterized morphologically through preparation of a wet portion which was examined microscopically (Rippka et al.,1979). The filamentous nature, size, shape of vegetative cells, presence of heterocyst and akinetes were identified.

\subsection{Molecular identification of cyanobacteria}

The cyanobacterial isolates were identified according to $16 \mathrm{~S}$ rRNA sequencing. The isolates were cultivated in BG-11 broth for 30 days. After centrifugation of the broth culture at $6000 \mathrm{~g}$ for $10 \mathrm{~min}$, the harvested biomass was washed three times using $0.85 \% \mathrm{NaCl}$ saline solution, and genomic DNA was extracted using GeneJET Genomic DNA purification Kit (ThermoFisher Scientific, Republic of Lithuania). The yield and purity of extracted DNA were checked using both UV-Vis NanoDrop spectrophotometer (NanoDrop 2000, ThermoFisher Scientific, Germany) and agarose gel electrophoresis (Bio-rad, USA).

The 16S rRNA gene fragments were amplified using the cyanobacteria specific primers CYA106F (5'-CGGACGGGTGAGTAACGCGTGA-3') and CYA781R (5'GACTACWGGGGTATCTAATCCCWTT-3') (Koo et al., 2019). The amplification step was performed using Thermal cycler PCR (Bio - Rad T100, USA). The PCR conditions for 16S rRNA gene were: initial denaturation step at $95^{\circ} \mathrm{C}$ for $12 \mathrm{~min}$, followed by 30 cycles of $94^{\circ} \mathrm{C}$ for $1 \mathrm{~min}, 56^{\circ} \mathrm{C}$ for $1 \mathrm{~min}$ and $72^{\circ} \mathrm{C}$ for $2 \mathrm{~min}$, and one extension step at $72^{\circ} \mathrm{C}$ for $10 \mathrm{~min}$. The PCR products were checked via agarose gel electrophoresis, purified using gel extraction kit and sequenced by Macrogen, Inc., Seoul, South Korea using automatic ABI 370×1 DNA Sequencer (Applied Biosystem, USA). The sequences were analyzed applying BLAST V2.0 software (http://www.ncbi.nlm.nih.gov/BLAST/).

\subsection{Phylogenic analysis of cyanobacteria isolates}

The Neighbor-Joining method was used to conclude the evolutionary history (Saitou and Nei, 1987). The tree was computed using the maximum composite likelihood method 
(Tamura et al., 2004). The analysis involved 13 nucleotide sequences of which 2 sequences of $16 \mathrm{~S}$ rRNA gene amplified from cyanobacterial isolates while 11 sequences representing the most similar hits were obtained from the NCBI gene bank database. Evolutionary analyses were conducted in MEGA5 software.

\subsection{Biosynthesis of silver nanoparticles (Ag-NPs) by cyanobacteria}

The cyanobacterial isolates were screened for synthesis of Ag-NPs extra- and intracellularly under light and dark conditions. According to the method of Patel et al. (2015), after 15 days incubation, the broth cyanobacterial cultures were centrifuged (Universal 16r, Hettich) at $6000 \mathrm{rpm} / 10 \mathrm{~min}$ at $10^{\circ} \mathrm{C}$.

For extracellular synthesis of Ag-NPs, the supernatant was added to $\mathrm{AgNo}_{3}$ solution to reach the final concentration of $1 \mathrm{mM} \mathrm{AgNO}$. To evaluate the synthesis of Ag-NPs intracellularly, the harvested biomass was washed twice at least with sterile distilled water, kept at $-20^{\circ} \mathrm{C}$ overnight to facilitate complete lysis of cells (Mahamuni et al., 2019), then 0.5 gram of wet weight biomass was suspended in $10 \mathrm{ml}$ of $1 \mathrm{mM} \mathrm{AgNO}$ solution, $\mathrm{pH} 7$. Both experiments were incubated at $30^{\circ} \mathrm{C} / 48 \mathrm{~h}$, either under direct light provided from fluorescent white lamps or in dark conditions provided through wrapping the tubes with aluminum foil. As a control, the $\mathrm{AgNO}_{3}$ solution, supernatant and 0.5 gram of wet weight biomass suspended in $10 \mathrm{ml}$ of sterile water were incubated under the same conditions.

\subsection{Characterization of Ag-NPs}

To apply some characterization tests, the dried nanoparticles are used. To prepare the dried Ag-NPs synthesized by isolated cyanobacteria, the Ag-NPs suspension obtained after incubation for $72 \mathrm{~h}$ was centrifuged at $6000 \mathrm{rpm}$ for $15 \mathrm{~min}$ at $10^{\circ} \mathrm{C}$. The pellet was washed 3 times with sterile distilled water, spread in Petri plates and dried at $30^{\circ} \mathrm{C}$ for $24 \mathrm{~h}$. The dried nanoparticles were scraped by a scalpel, harvested, weighted and stored in sterile microtube for quantitative estimation (Hamida et al., 2020).

The following characterization tests were applied to confirm the formation of Ag-NPs by isolated cyanobacteria.

\subsubsection{Visual Color Change Test}

Formation of silver nanoparticles was detected by the visual color change from pale yellow to brownish color within the incubation time.

\subsubsection{Ultraviolet - Visible (UV-Vis) spectroscopic analysis}

In time intervals of 1 and $24 \mathrm{~h}, 1 \mathrm{ml}$ from each sample was centrifuged at $6000 \mathrm{rpm}$ for $5 \mathrm{~min}$. The absorption measurements in the wavelength range of 300-550 nm were estimated using UV-Vis spectroscopy (Specord 210 plus, Analytic Jena, Germany). The isolates showed an absorption peak in the range between 400 and $450 \mathrm{~nm}$ were considered as silver nanoparticle-producing cyanobacteria (Sadowski, 2010).

\subsubsection{Scanning electron microscopy (SEM)}

After 48h, SEM was used to characterize the surface morphology of nanoparticles at an accelerating voltage of $30 \mathrm{kV}$. The Ag-NPs solution was centrifuged, and the pellet was allowed to dry. The dried nanoparticles were examined through coated with gold by a coater to prevent building-up the electrical charges (Keskin et al., 2016). Also, Ag-NPs were characterized in a particle suspension.

\subsubsection{Transmission electron microscopy (TEM)}

TEM gives 1,000 fold higher morphological resolution for both size and shape compared to SEM (Sadowski, 2010). Two-dimensional and high-resolution Ag-NPs images were captured with TEM, Jeol, JEM-1400, Japan. A drop of Ag-NPs suspension was placed on copper-grid carbon coated with 300 mesh palladium and carbon, and allowed to dry. The Ag-NPs morphology was observed by TEM processed at an operating voltage of $80 \mathrm{kV}$. 


\subsubsection{X-ray diffraction (XRD) analysis.}

The crystal structure of Ag-NPs was characterized using "x-ray-dx pert pro panalytical diffractometer". The powdered Ag-NPs were penetrated by X-rays and scanned across the region of $2 \theta$, from range $0^{\circ}$ to $80^{\circ}$.

\subsubsection{Energy dispersive X-ray (EDX)}

EDX was used to determine elemental composition of metal nanoparticles. Energy dispersive X-ray spectroscopy uses nature advantages of light photons. Generally, EDX operates by recording X-ray signals, energy and intensity distribution which are generated using a focused electron beam (Sadowski, 2010 and Gowramma et al., 2015). Analysis was processed with EDAX FEI INSPECT instrument across layout: kv: 25.00; take-off: 34.58; tilt: 0.00; ampt: 102.4; resolution: 129.66; detector type: sutw-sapphire; edax zaf quantification standardless sec.

\subsubsection{Fourier transform infrared spectrometer (FT-IR) analysis}

The chemistry and variations of functional groups attached to Ag-NPs surface were identified with FT-IR spectrometer (NICOLET 380, China). The dried nanoparticles were mixed with potassium bromide in a ratio of 1:100. The sample of $100 \mu$ was placed in the attenuated total reflectance (BRUKER) analyzer. The silver nanoparticle solution was analyzed by ATR-FT-IR. The IR ray's spectrum is scanned across $4000-400 / \mathrm{cm}$ with diffuse reflectance mode (DRS-800) within $4 \mathrm{~cm}^{-1}$ resolution (Sadowski, 2010) (https://www IR Spectrum Table \& Chart, Sigma-Aldrich).

\subsection{Antibacterial efficiency of Ag-NPs}

The antibacterial activity of Ag-NPs synthesized by isolated cyanobacteria was assessed applying well diffusion assay (Jena et al., 2013) against 6 bacterial strains including $\mathrm{G}^{+}$and $\mathrm{G}^{-}$bacteria. These bacterial strains were Bacillus cereus ATCC 10876, Methicillin resistant Staphylococcus aureus (MRSA) ATCC 43300, Micrococcus luteus ATCC 10240, Pseudomonas aeruginosa ATCC 9027, Salmonella typhimurium ATCC 14028 and Escherichia coli $\mathrm{O} 157: \mathrm{H} 7$ wild type strain 93111 as a representative enterohaemorrhagic $E$. coli (EHEC). The broth culture of each bacterial strain was prepared in soyabean casein digest broth (OXOID) with incubation at the optimum temperature/24h. The optical density (OD 600 ) of each culture was adjusted to $0.5 \pm 0.1$ using the UV/Vis spectrophotometer. Using sterile cotton swabs, each individual culture was spread on the surface of nutrient agar, in which the wells of $10 \mathrm{~mm}$ diameter were prepared using a sterile cork borer. Each well was filled with $100 \mu \mathrm{l}$ either from vancomycin hydrochloride $(100 \mathrm{mg} / \mathrm{ml})$ as a positive control, $100 \mu \mathrm{Ag}$-NPs resulting solution $(1 \mathrm{mM})$ or $\mathrm{AgNO}_{3}$ solution $(1 \mathrm{mM})$ or. The plates were incubated for $24 \mathrm{~h}$ at the optimum temperature for each microbe. The inhibitory effect of $\mathrm{Ag}$ NPs was estimated through measuring the inhibition zone diameter. Also, the relative inhibition percentage was calculated according to the next formula (Kumar et al., 2010): Relative percentage inhibition of Ag-NPs $=(100 *(y-x)) / z-y$ as:

$\mathrm{x}$ : total inhibition area of Ag-NPs; y: total inhibition area of $\mathrm{AgNO}_{3}$ solution $1 \mathrm{mM}$ and $\mathrm{z}$ : total inhibition area of the standard drug.

\subsection{Antioxidant activity of Ag-NPs}

The capability of cyanobacterial Ag-NPs to scavenge 2,2-diphenyl-1-picrylhydrazyl (DPPH) radicals was assessed through mixing $100 \mu \mathrm{l}$ of tested Ag-NPs resulting solution with $1 \mathrm{ml}$ from methanolic solution of $0.1 \mathrm{mM}$ DPPH. The mixture was vortexed and incubated at $37^{\circ} \mathrm{C}$ for $30 \mathrm{~min}$ in dark. The absorbance of the samples was measured at 515 $\mathrm{nm}$. The free radical scavenging activity was calculated using the following equation: DPPH scavenging activity $(\%)$ (antioxidant activity, \%) $=\left(\left(\mathrm{A}_{0}-\mathrm{A}_{1}\right) / \mathrm{A}_{0}\right) * 100$ where: $\mathrm{A}_{0}$ is the absorbance of the control reaction and $\mathrm{A}_{1}$ is the absorbance of reaction mixture (Hamouda et al., 2017). 


\section{Results and Discussion}

\subsection{Cyanobacteria identification by Light microscope examination}

Two isolates of cyanobacteria (AM5E and AM6E) were purified and characterized morphologically according to Rippka et al. (1979). The AM5E and AM6E isolates were characterized as filamentous and non heterocystous cyanobacteria (Fig. 1A - 1D). The filaments were unbranched. No gas vacuoles were observed within the cells. The filaments of AM5E were long, thin, straight or slightly curvy, and non-constructed. Also, they were motile and had sharp apical terminals. The filaments may exist in a separate state or in bundles. The filaments of AM6E isolate were thicker, and exist as separate filaments (Fig. 1C and D). The filaments were slightly motile and had round ends.

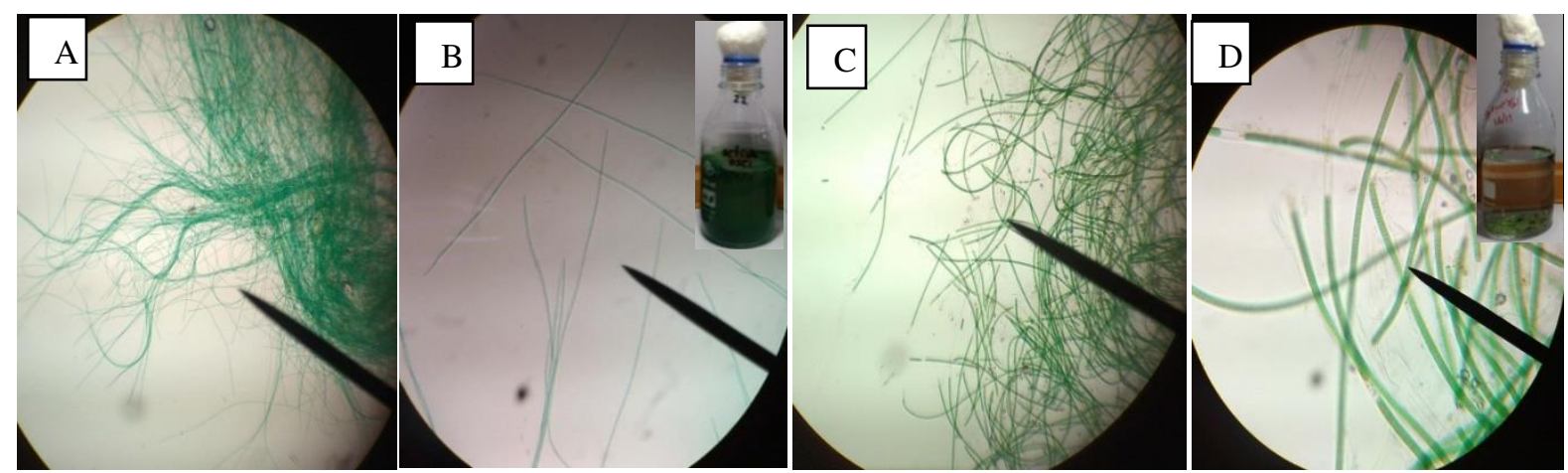

Fig. 1. Light micrographs of cyanobacterial isolates AM5E (A: 10x, B: 40x) and AM6E (C: 10x, D: 40x).

\subsection{Molecular identification and phylogenetic analysis of cyanobacterial isolates}

According to $16 \mathrm{~S}$ rRNA gene sequence of the two isolates, AM5E showed $100 \%$ similarity to Desertifilum tharense and Desertifilum dzianese, while AM6E showed 99.6\% similarity to Phormidium ambiguum. The phylogenetic relatedness was confirmed in the neighbor joining tree (Fig. 2). Sequences were deposited in the NCBI GenBank as Desertifilum tharense AM5E (accession number: MW762709) and Phormidium ambiguum AM6E (accession number: MW762710).

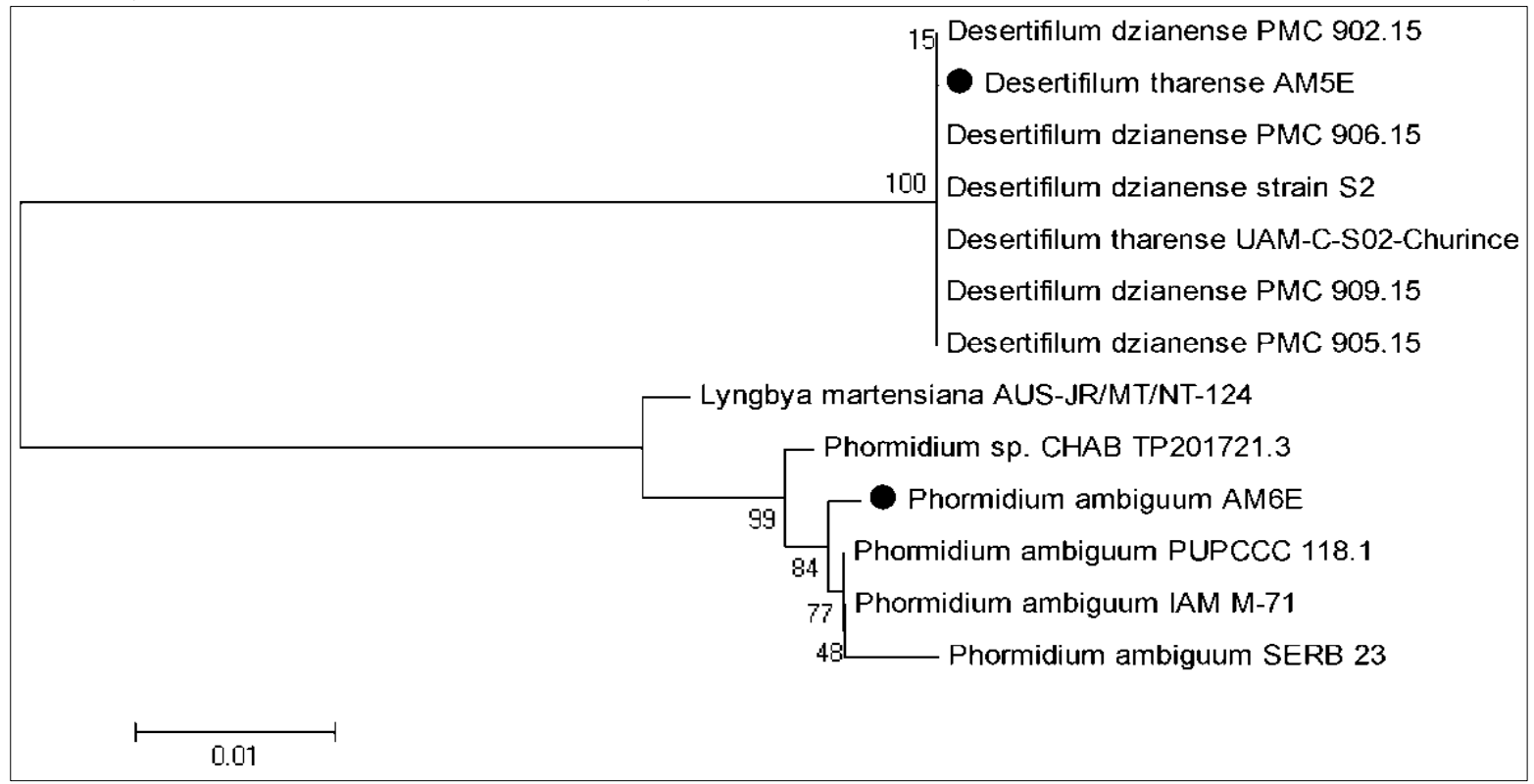

Fig. 2. A neighbor-joining phylogenetic tree (dark circles) with the closest hits obtained from the NCBI gene bank. 


\subsection{Characterization of biosynthesized silver nanoparticles (Ag-NPs) by cyanobacteria}

Generally, silver nanoparticles are synthesized through two pathways comprising enzymatic and non-enzymatic reduction (Otari et al., 2015). The nitrate reductase enzyme, which involves in enzymatic synthesis of silver nanoparticles, converts nitrate to nitrite and an electron shuttle is induced thus reducing the silver ions to silver nanoparticles. The enzymatic production of silver nanoparticles is fast and non-toxic approach. Conversely, the non-enzymatic synthesis of Ag-NPs depends on chemical reduction of silver atoms using reducing and stabilizing compounds produced by plants or microorganisms.

\subsubsection{Visual color change}

Reduction of silver atoms into silver nanoparticles extra- and intracellularly using isolated cyanobacteria could be observed visually through the color change from pale yellow to brown. Generally, this process is time dependent as the intensity of brown color is directly proportional to reaction time (Khan et al., 2019). Saifuddin et al. (2009) reported that the changing in color was due to the excitation of surface plasmon vibrations in the resultant nanoparticle. The Ag-NPs produced by cyanobacteria were observed to be highly stable for a variant time ranged from 1 to $120 \mathrm{~h}$ (Govindaraju et al., 2009).

In this study, the brown color was observed after $1 \mathrm{hr}$, either for Desertifilum tharense (Fig. 3) or Phormidium ambiguum (Fig. 4) indicating their ability to synthesize Ag-NPs extra- and intracellularly under both light and dark conditions. For the both isolates, after 48 hours, the darkest brown color was perceived under light conditions for extra- and intracellularly produced Ag-NPs. Comparing the intra- and extracellular biosynthesis of AgNPs, the dark brown color was evidence for promising extracellular biosynthesis by Desertifilum tharense or Phormidium ambiguum. Therefore, further characterization testes, antibacterial and antioxidant activity were assessed for Ag-NPs synthesized extracellularly under light conditions.
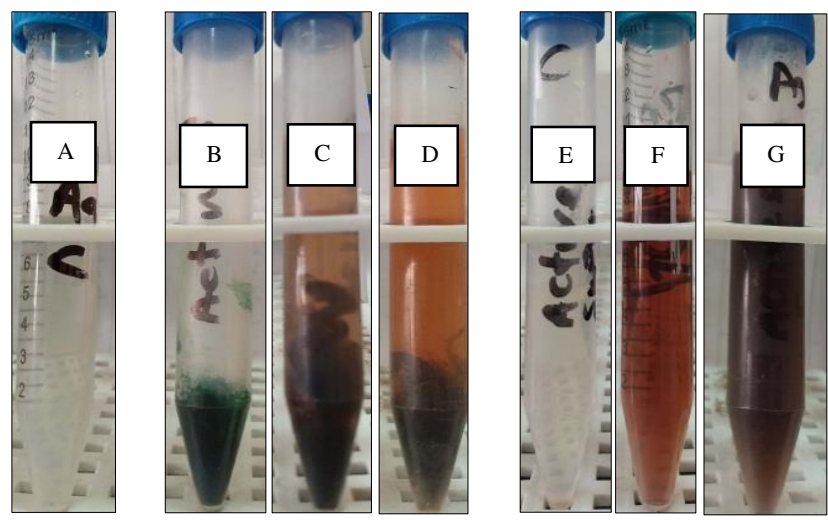

Fig. 3. Color change during the reduction process of silver to Ag-NPs extra and intracellularly using Desertifilum tharense. A, $1 \mathrm{mM}$ silver nitrate solution (control 1). B, cell suspension in water (control 2). C, formation of Ag-NPs intracellularly under dark conditions after $48 \mathrm{~h}$. $\mathrm{D}$, formation of Ag-NPs intracellularly under light conditions after 48 h. E, cell free supernatant (control 3). F, formation of Ag-NPs extracellularly under dark conditions after $48 \mathrm{~h}$. G, formation of Ag-NPs extracellularly under light conditions after $48 \mathrm{~h}$.
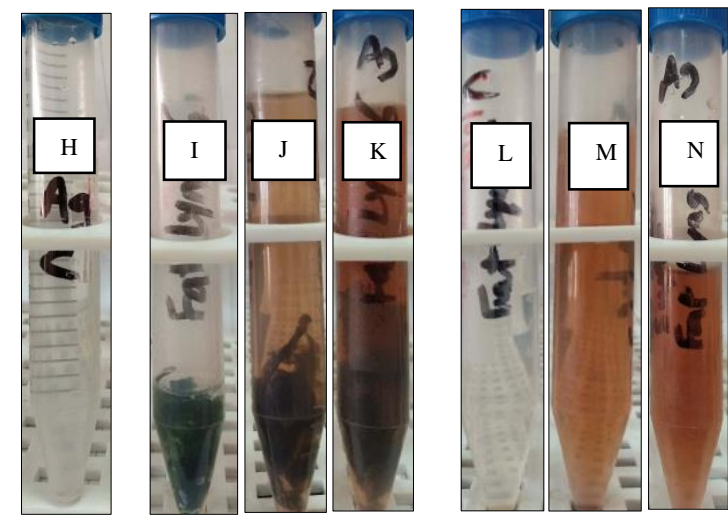

Fig. 4. Color change during the reduction process of silver to Ag-NPs extra and intracellularly using Phormidium ambiguum. H, $1 \mathrm{mM}$ silver nitrate solution (control 1). I, cell suspension in water (control 2). J, formation of Ag-NPs intracellularly under dark conditions after $48 \mathrm{~h}$. $\mathrm{K}$, formation of Ag-NPs intracellularly under light conditions after 48 h. L, cell free supernatant (control 3). M, formation of Ag-NPs extracellularly under dark conditions after $48 \mathrm{~h}$. $\mathrm{N}$, formation of Ag-NPs extracellularly under light conditions after $48 \mathrm{~h}$.

\subsubsection{UV-Vis spectrophotometer analysis}

Formation of Ag-NPs detected by visual observation of color change was further confirmed by sharp peaks given in the visible region from UV-Vis spectrum. Ag-NPs 
characterization using UV-visible spectrophotometer is considered the most widely technique (Sun et al., 2001; Gowramma et al., 2015). In this study, UV-Vis spectrophotometer analyses were carried out at absorbance spectrum range of $300-550 \mathrm{~nm}$ for Ag-NPs synthesized extracellularly under light conditions.

For Desertifilum tharense, Ag-NPs gave the sharp SPR (surface plasmon resonance) peak at $450 \mathrm{~nm}$ after one hour (Fig. 5A). With increasing reaction time reached $24 \mathrm{~h}$, the peak shifted to shorter wavelength region as two peaks appeared at 410 and $435 \mathrm{~nm}$ (Fig. 5B). Kathiraven et al. (2014) reported that when SPR band moves towards shorter wavelength that means a decrease in particle size. This phenomenon was not observed for Ag-NPs synthesized by Phormidium ambiguum as the SPR peak appeared at $450 \mathrm{~nm}$ after 1 and 24 hours (Fig. 6A and 6B).
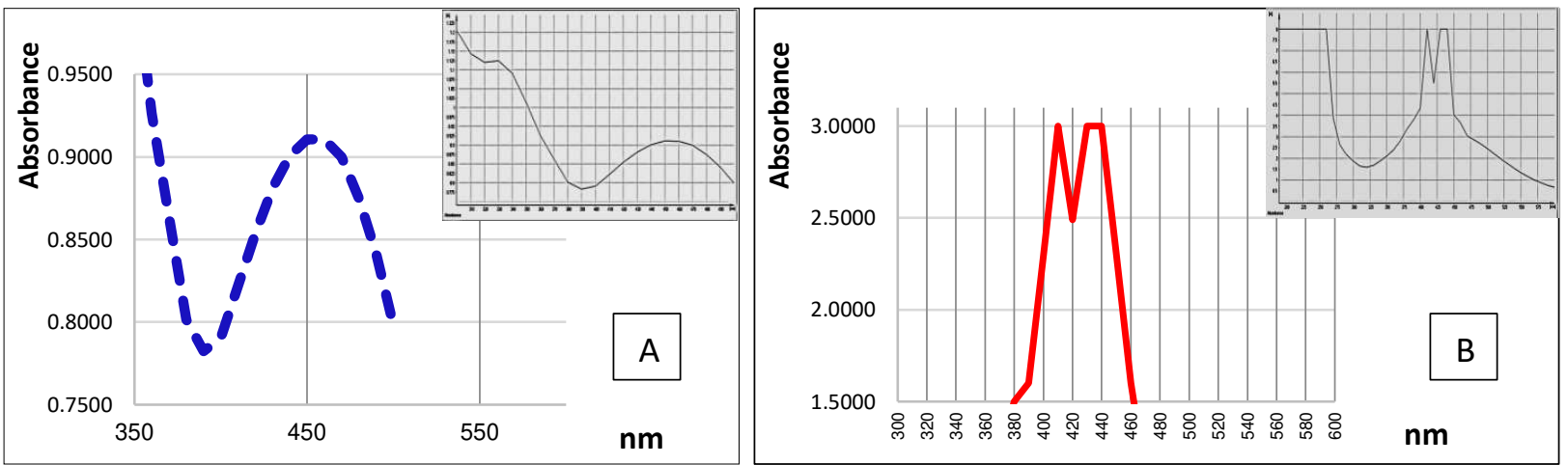

Fig. 5. UV-Vis absorption spectra of Ag-NPs synthesized extracellularly by Desertifilum tharense after $1 \mathrm{~h}$ (A) and after 24h (B).

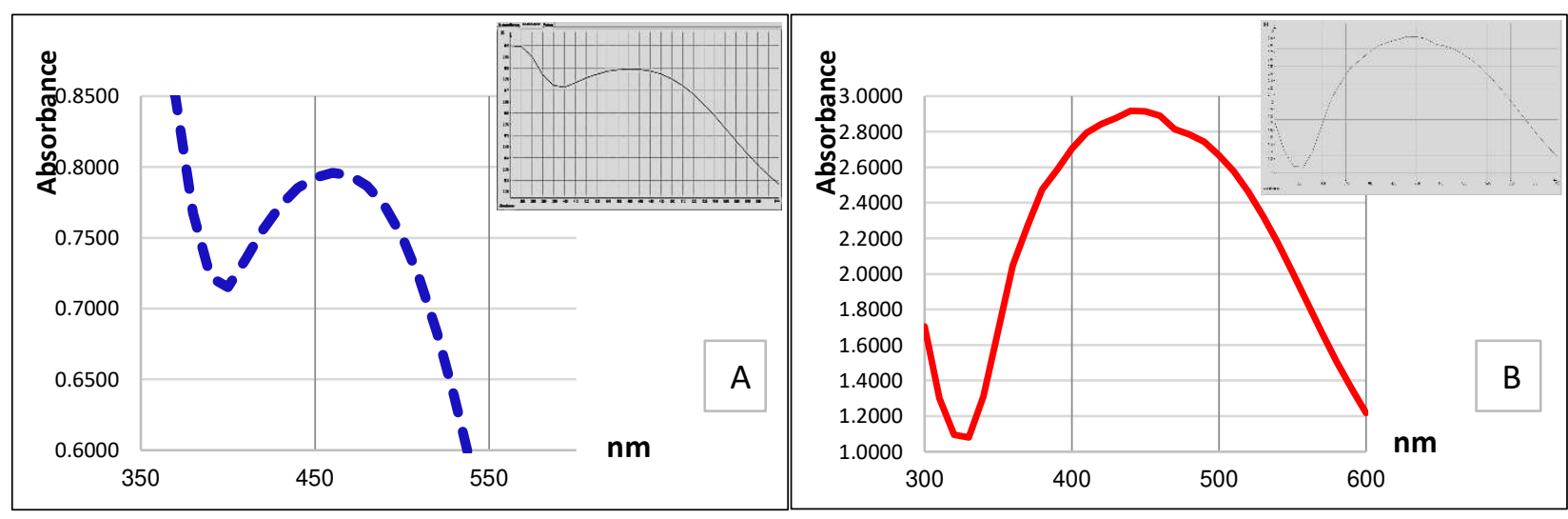

Fig. 6. UV-visible absorption spectra of Ag-NPs synthesized extracellularly by Phormidium ambiguum after $1 \mathrm{~h}(\mathrm{~A})$ and after $24 \mathrm{~h}(\mathrm{~B})$.

It was known that Ag-NPs give the plasmon resonance peak in absorption spectrum between 410 - $450 \mathrm{~nm}$ (Kashyap et al., 2019). Consequently, the results confirmed successful extracellular Ag-NPs synthesis by Desertifilum tharense and Phormidium ambiguum under light conditions.

\subsubsection{Scanning and Transmission electron microscopy}

Scanning electron microscopy (SEM) micrographs indicated the presence of Ag-NPs produced by Desertifilum tharense (Fig. 7A and 7B) and Phormidium ambiguum (Fig. 8A and 8B) as irregular polydisperse clusters of particles.

The Ag-NPs were further characterized for shape and size determination by transmission electron microscopy (TEM). The TEM micrographs (7C) and (8C) showed spherical shape of Ag-NPs produced by Desertifilum tharense and Phormidium ambiguum, 
respectively with good particles dispersal without agglomeration. Also, TEM micrographs displayed the size of particles in a range of $6.24-11.7 \mathrm{~nm}$ and $6.46-12.2 \mathrm{~nm}$ for Ag-NPs produced by Desertifilum tharense and Phormidium ambiguum, correspondingly. The SPR peak at $435 \mathrm{~nm}$ of Ag-NPs synthesized by Desertifilum tharense confirmed the spherical shape of these particles as reported by Govindaraju et al. (2009).

Generally, the cyanobacterial silver nanoparticles are found in different shapes. Patel et al. (2015) studied the shape of Ag-NPs produced by different cyanobacterial strains. They found that the Ag-NPs produced by Anabaena sp. and Limnothrix sp. appeared as elongated particles, while Ag-NPs of Coelastrum sp. and Botryococcus braunii appeared with spherical shape. The particles formed by Synechocystis sp. were irregular clusters.

The size of Ag-NPs produced by Desertifilum tharense and Phormidium ambiguum was in a range reported by Singh et al. (2014). In other studies, the size of particles produced by cyanobacteria was larger. Rashed et al. (2018) produced Ag-NPs with an average size of $60 \mathrm{~nm}$ from Convolvulus arvensis extract. The average size of Ag-NPs from Chlorella sp. was $90.6 \mathrm{~nm}$ (Kashyap et al., 2019). Some cyanobacterial cultures synthesized silver particles with a size larger than $100 \mathrm{~nm}$. Keskin et al. (2016) and Kashyap et al. (2019) produced particles with average size of $140 \mathrm{~nm}$ from Synechococcus sp., and size of 136.2 and 241.8 $\mathrm{nm}$ from Scenedesmus vacuolatus and Lyngbya putealis, respectively.
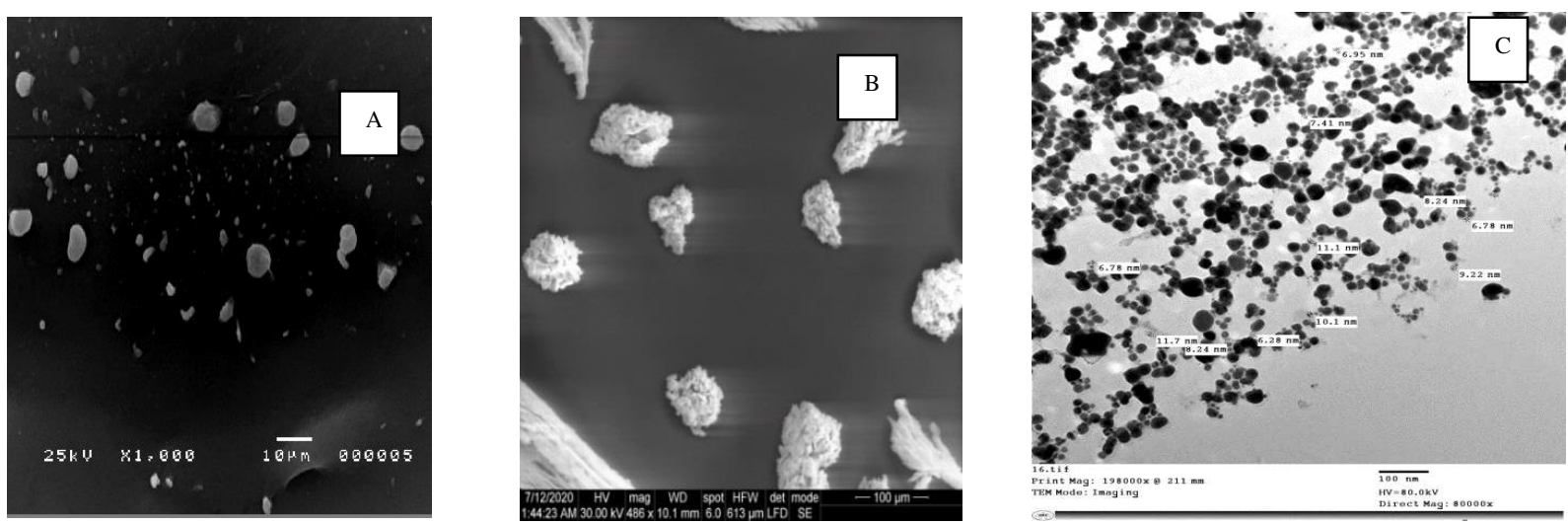

Fig. 7. SEM micrographs of suspended Ag-NPs (A) and dried Ag-NPs (B) obtained from Desertifilum tharense. TEM micrographs of Ag-NPs (C) showed the spherical shape of Ag-NPs with a size of 6.24-11.7 nm.
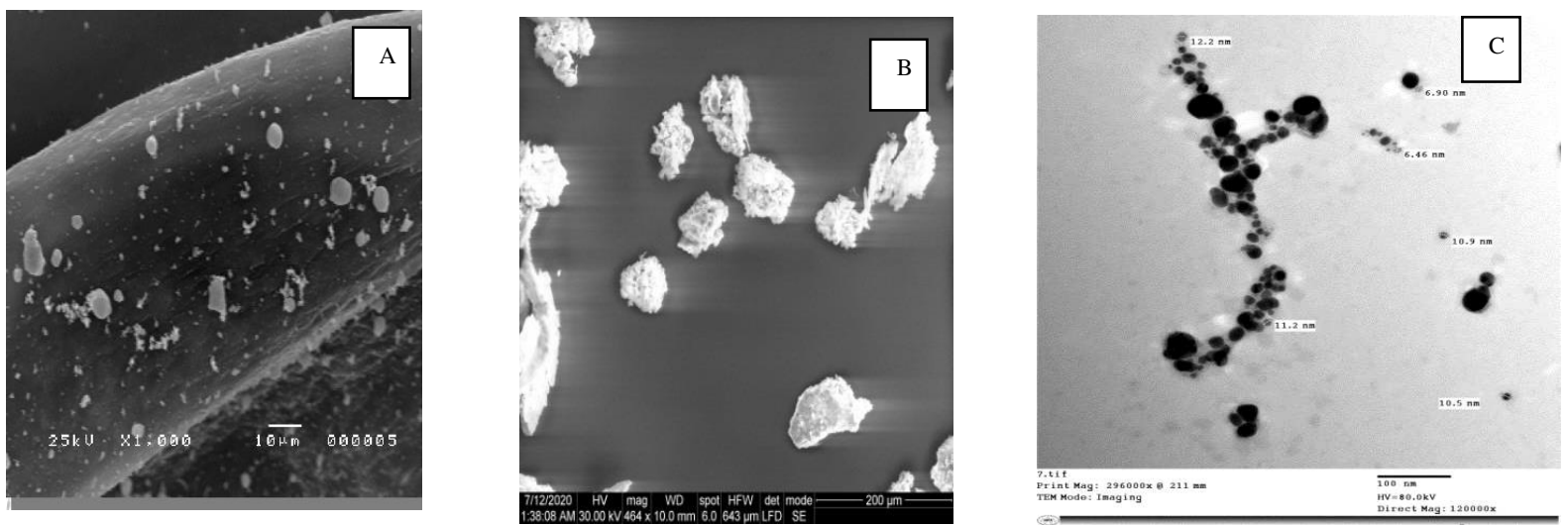

Fig. 8. SEM micrographs of suspended Ag-NPs (A) and powder Ag-NPs (B) obtained from Phormidium ambiguum. TEM micrographs of Ag-NPs (C) showed the spherical shape of Ag-NPs with a size of 6.46$12.2 \mathrm{~nm}$.

\subsubsection{X-ray diffraction (XRD) analysis}

$\mathrm{X}$-ray diffraction analysis (XRD) is a technique used to determine the crystallographic structure of a material through irradiating it with X-rays and measuring the intensities and 
scattering angles of the X-rays that leave the material. XRD pattern was investigated in the range of $0^{\circ}$ to $80^{\circ}$ at diffraction angle of Pos $\left({ }^{\circ} 2 \mathrm{Th}\right.$.).

The diffractogram of Desertifilum tharense Ag-NPs (Fig. 9A) showed five main peaks of $32.19^{\circ}, 38.089^{\circ}, 44.2567^{\circ}, 64.4547^{\circ}$ and $77.4727^{\circ}$ corresponding to (101), (111), (200), (220) and (311) lattice planes, respectively which were indexed in Joint Committee on Powder Diffraction Standards (JCPDS) file no. 84-0713 and 04-0783 as reported by Mahiuddin et al. (2020). Similar diffraction peaks were identified for Phormidium ambiguum Ag-NPs (Fig. 9B).
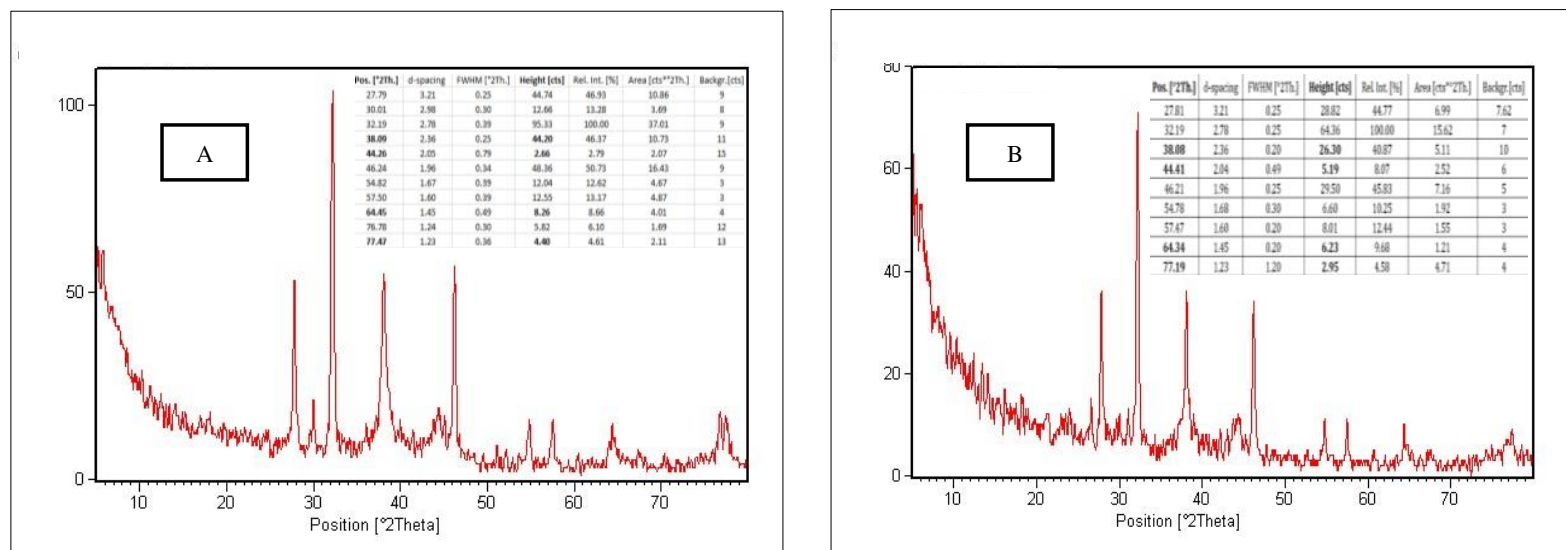

Fig. 9. XRD pattern of Ag-NPs synthesized extracellularly by Desertifilum tharense (A) and Phormidium ambiguum (B).

The results of XRD analysis confirmed that the biosynthesized Ag-NPs have face centered cubic (fcc) structure.

it was noticed that there are additional peaks at $54.82^{\circ}$ and $57.5^{\circ}$ in the diffractogram of Desertifilum tharense Ag-NPs, and at $54.78^{\circ}$ and $57.47^{\circ}$ in that of Phormidium ambiguum Ag-NPs. These peaks could be attributed to the presence of unreduced $\mathrm{AgNO}_{3}$ as stated by Mehta et al., (2017).

\subsubsection{EDX analysis}

The purity, elemental constituents and relative abundance of Ag-NPs synthesized by Desertifilum tharense and Phormidium ambiguum were analyzed by means of Energy Dispersive X-ray (EDX) as presented in Figures (10A) and (10B), respectively.

In Figures (10A) and (10B), two peaks were observed at 3.0 and $3.2 \mathrm{keV}$ for silver nanoparticles revealing the presence of pure metallic Ag-NPs (Magudapathy et al., 2001; Patel et al., 2015).

In case of Desertifilum tharense Ag-NPs, EDX analysis (Fig. 10A) suggested that the powder has high purity and intensity as the two emission peaks of metal silver shows more than $49 \%$. The percentage relative composition of elements was Carbon (C) 23.88\%, Oxygen (O) $12.81 \%$, Chlorine (Cl) $6.95 \%$, Sodium (Na) 5.2\%, Silicon (Si) $0.9 \%$ and Sulfur (S) $0.51 \%$. While in case of Phormidium ambiguum, EDX characterization (Fig.10B) exhibited less purity and weight as the two emission peaks of metal silver represents only more than $32 \%$. The percentage relative composition of elements was Carbon (C) 41.6\%, Oxygen (O) 12.33\%, Chlorine (Cl) 3.7\%, Sodium (Na) 3.65\%, Iron (F) 2.85, Arsenic (As) 0.95\%, Silicon (S) $0.41 \%$, Sulfur $(\mathrm{S}) 0.98 \%$ and Calcium $(\mathrm{Ca}) 0.68 \%$.

XRD and EDX results clearly confirm the successful synthesis of Ag-NPs in its oxide form or chloride form. 

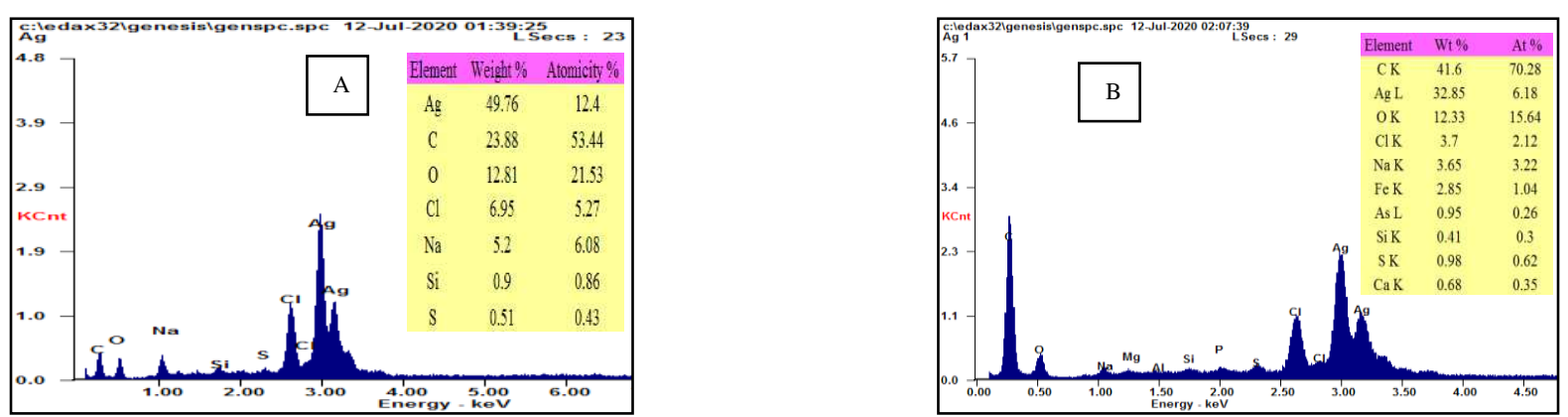

Fig. 10. EDX quantitative analysis and spectra of Ag-NPs synthesized by Desertifilum tharense (A) and Phormidium ambiguum (B).

\subsubsection{Transform Infrared Spectroscopy (FTIR)}

The structure of organic compounds on the surface of AgNPs was investigated using FTIR Spectroscopy.

The FTIR spectrum of Ag-NPs synthesized by Desertifilum tharense and Phormidium ambiguum specified peaks around 3450, 2065, 1634 and $428 \mathrm{~cm}^{-1}$ (Fig. 11). Strong absorption peak at $3450 \mathrm{~cm}^{-1}$ assigned to O-H stretching vibration of polysaccharides, and N$\mathrm{H}$ stretching vibration of proteins. This indicates the polysaccharides and proteins found in extracellular extract may play role in synthesis of Ag-NPs (Hamida et al., 2020; Mahiuddin et al., 2020). Also, the polysaccharides and proteins, as organic capping agents, may contribute in particles stabilization. Jena et al. (2013) reported that the capping peptide can bind to nanoparticles by free amino groups or by different residues inside the proteins. The peak around $1634 \mathrm{~cm}^{-1}$ attributed to stretching vibration of $\mathrm{C}=\mathrm{O}$ in amides (Mahiuddin et al., 2020). The peak at $428 \mathrm{~cm}^{-1}$ is related to binding Ag-NPs with oxygen from hydroxyl groups (AL-Katib et al., 2015).

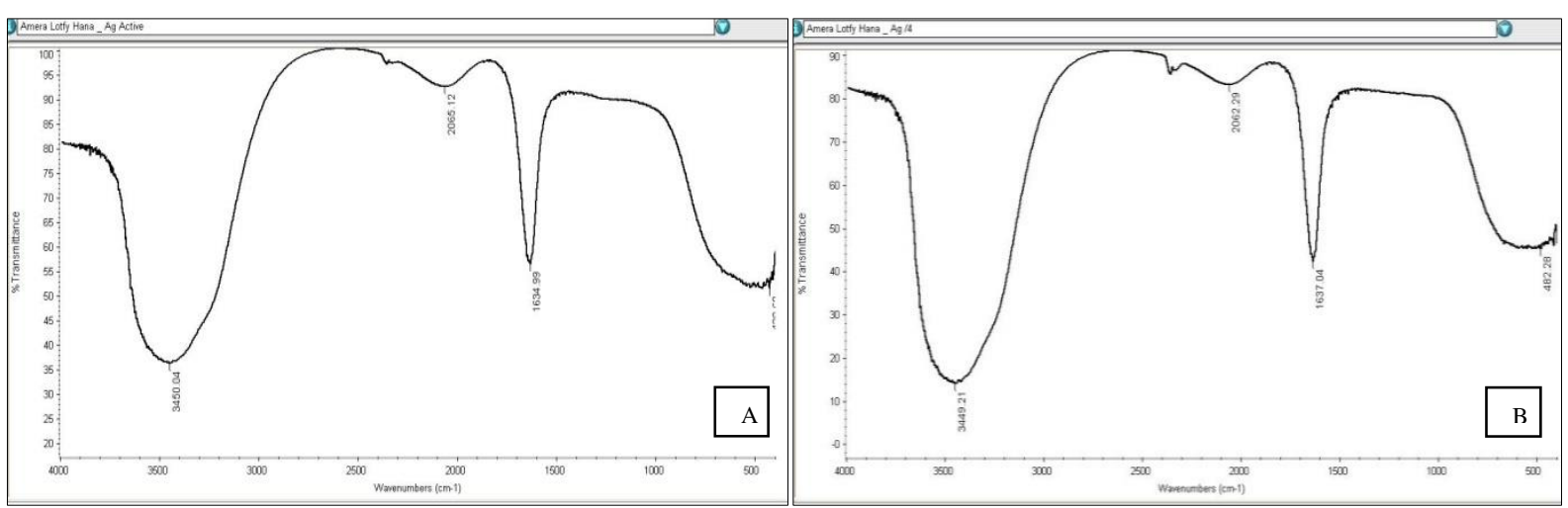

Fig. 11. FTIR spectra of Ag-NPs synthesized extracellularly from Desertifilum tharense (A) and Phormidium ambiguum (B).

\subsection{Antibacterial activity}

Currently, using nanoparticles as antimicrobial agents are gaining excessive interest. Generally, the nanoparticles are evaluated as antimicrobials alone or in combination with antibiotics. The nanoparticles can increase antimicrobial effect of some antibiotics against G+ and G- bacteria (Li et al., 2011).

In this study, 6 bacterial pathogens were selected as indicator microorganisms for screening the antibacterial activity of Ag-NPs synthesized extracellularly under light conditions by the two isolated cyanobacteria. The results were compared with vancomycin hydrochloride $(100 \mathrm{mg} / \mathrm{ml})$ and $\mathrm{AgNO}_{3}(1 \mathrm{mM})$ for evaluating the relative percentage inhibition of Ag-NPs. 
Desertifilum tharense Ag-NPs displayed the largest inhibition zone ranged from $9 \mathrm{~mm}$ against Micrococcus luteus ATCC 10240 to $25 \mathrm{~mm}$ against methicillin resistant $S$. aureus (MRSA) ATCC 43300 (Table 1). The greatest relative percentage inhibition was recorded against S. typhimureum ATCC 14028 (129.6\%), followed by MRSA ATCC 43300 and E. coli O157:H7 wild type strain 93111 (100\%).

For Phormidium ambiguum Ag-NPs, the inhibition zone diameter was in a range of 9 - $18 \mathrm{~mm}$. Maximum relative percentage inhibition of $86.6 \%$ was displayed against Salmonella typhimureum ATCC 14028, followed by E. coli O157:H7 wild type strain 93111 (81.7\%) and P. aeruginosa ATCC 9027 (75.1\%).

Table 1. Inhibition zone diameter $(\mathrm{mm})$ and relative percentage inhibition of Ag-NPs synthesized extracellularly from Desertifilum tharense and Phormidium ambiguum under light conditions.

\begin{tabular}{|l|c|c|c|c|}
\hline \multirow{2}{*}{ Indicator microorganisms } & \multicolumn{2}{|c|}{ Desertifilum tharense Ag-NPs } & \multicolumn{2}{c|}{ Phormidium ambiguum Ag-NPs } \\
\cline { 2 - 5 } & $\begin{array}{c}\text { Inhibition } \\
\text { zone (mm) }\end{array}$ & $\begin{array}{c}\text { Relative percentage } \\
\text { inhibition }(\%)\end{array}$ & $\begin{array}{c}\text { Inhibition } \\
\text { zone (mm) }\end{array}$ & $\begin{array}{c}\text { Relative percentage } \\
\text { inhibition (\%) }\end{array}$ \\
\hline B. cereus ATCC 10876 & 12 & 84.8 & 9 & 58.2 \\
\hline MRSA ATCC 43300 & 25 & 100.0 & 17 & 44.8 \\
\hline M. luteus ATCC 10240 & 9 & 45.0 & 9 & 45.0 \\
\hline $\begin{array}{l}\text { S. typhimureum } \\
\text { ATCC 14028 }\end{array}$ & 17 & 129.6 & 13 & 86.6 \\
\hline $\begin{array}{l}\text { P. aeruginos } \\
\text { ATCC 9027 }\end{array}$ & 14 & 87.1 & 18 & 75.1 \\
\hline $\begin{array}{l}\text { E. coli O157:H7 wild type } \\
\text { strain 93111 }\end{array}$ & 21 & 100.0 & & 81.7 \\
\hline
\end{tabular}

The antibacterial effect of silver nanoparticles is size, charge and shape dependent. The great antibacterial activity of Desertifilum tharense Ag-NPs against tested pathogenic bacteria could be attributed to their particle size $(6.24-11.7 \mathrm{~nm})$ which was smaller than that of Phormidium ambiguum Ag-NPs (6.46 - $12.2 \mathrm{~nm}$ ). This is in accord with the findings of Ivask et al. (2014) Patel et al. (2015) who found that the antibacterial activity of Ag-NPs is inversely proportional with their particle size as smaller size means larger surface area which facilitates the interaction between nanoparticles and microbial cells. The particles with size of $10 \mathrm{~nm}$ or smaller can easily penetrate the bacterial cell wall and interact with the cytosol biomolecules. It was known that the antibacterial activity of Ag-NPs is not attributed only to the small size but also to their positive charge. Generally, positively charged particles electrostatically bind to lipopolysaccharides on the outer membrane of $\mathrm{G}^{-}$bacteria or lipoteichoic acids on the surfaces of $\mathrm{G}^{+}$bacteria which facilitate the cell penetration (Glinel et al., 2012). Rajeshkumar et al. (2014) and Otari et al. (2015) found that spherical shape with small size of Ag-NPs increase the contact area that ensuring the elimination of bacterial growth.

In general, the mode of action of Ag-NPs as antibacterial mainly includes loss the outer membrane integrity in $\mathrm{G}^{-}$bacteria, and permeabilization of the bacteria cell membrane through formation of pores across it resulting in releasing the cellular material and causing cell death ((Raffi et al., 2008 and Dehkordi et al., 2011). On the other hand, the pores formed in the cell membrane facilitate the Ag-NPs inflowing into the cell to combine with proteins containing sulfur and DNA causing DNA and enzymes damage, and leading to blocking vital metabolic processes (Hamouda et al., 2019).

\subsection{Free radical scavenging potential of Ag-NPs}

The results confirmed the highest scavenging activity of cyanobacterial Ag-NPs comparing with cyanobacterial extracellular extract. Silver nanoparticles of Phormidium 
ambiguum exhibited the highest scavenging activity of $48.7 \%$ comparing with that of Desertifilum tharense which displayed $43.753 \%$ (Table 2).

Table 2. Antioxidant capacity (\%) of Ag-NPs synthesized extracellularly from Desertifilum tharense and Phormidium ambiguum under light conditions.

\begin{tabular}{|c|c|c|c|c|c|}
\hline \multirow{2}{*}{$\begin{array}{c}\text { Tested cyanobacterial } \\
\text { strains }\end{array}$} & \multicolumn{3}{|c|}{ Absorbance at 515 nm } & \multicolumn{2}{c|}{ DPPH scavenging effect (\%) } \\
\cline { 2 - 6 } & $\begin{array}{c}\text { Methanolic } \\
\text { DPPH }\end{array}$ & $\begin{array}{c}\text { Extracellular } \\
\text { extract }\end{array}$ & Ag-NPs & $\begin{array}{c}\text { Extracellular } \\
\text { extract }\end{array}$ & Ag-NPs \\
\hline Desertifilum tharense & 0.770 & 0.492 & 0.433 & 36.143 & 43.753 \\
\hline Phormidium ambiguum & 0.770 & 0.508 & 0.395 & 33.974 & 48.701 \\
\hline
\end{tabular}

\section{Conclusion}

In this study, Egyptian cyanobacterial isolates of Desertifilum tharense and Phormidium ambiguum are found to be potent for the green synthesis of Ag-NPs extra- and intracellularly under light and dark conditions. They can produce smaller spherical particles with face-centered cubic structures. Presence of amides and hydroxyl groups indicate that proteins and polysaccharides could be considered as important factors in the Ag-NPs biosynthesis. Generally, the characterization assay showed that a Novel Desertifilum tharense cyanobacteria have superior power in green synthesis of AgNPs. The current findings indicate that Ag-NPs may be potent antibacterial agents against different pathogenic bacteria and could be used as alternatives to antibiotics. Further studies are recommended to define the optimal conditions for Ag-NPs biosynthesis. Also, more biological characterizations and in vivo experiments are required to establish the real potential for their application in medical and food sectors.

\section{Declarations}

\section{List of abbreviations;}

NPs, nanoparticles; Ag-NPs silver nanoparticles; AgNO3, silver nitrate; nm, nanometer; $\mu \mathrm{L}$, microliter; mg, milligram; min, minute; $\mathrm{h}$, hour; $\mathrm{mL}$, milliliter; $\mathrm{mM}$, millimolar; $\mu \mathrm{g}$, microgram; $\mathrm{cm}^{-1}$ , inverse centimeter; rpm, revolutions per minute; PCR, polymerase chain reaction; TEM, transmission electron microscope; SEM, scanning electron microscope; FTIR, Fourier transform infrared spectroscopy; UV-vis, ultraviolet-visible spectroscopy; XRD, X-ray diffraction; kb, kilobase; $\mathrm{kV}$, kilovolt; SPR, surface plasmon resonance; JCPDS, Joint Committee on Powder Diffraction Standards; DPPH, 2,2-diphenyl-1-picrylhydrazyl.

\section{Availability of data and materials:}

The data supporting this article are available in our Figures and Tables. The data sets analyzed in the present study are available from the corresponding author upon reasonable request.

\section{Ethics approval and consent to participate:}

Not applicable. The manuscript does not involve any animals, humans, human data, human tissue or plants.

\section{Consent for publication:}

Not applicable. The manuscript does not contain any individual person's data in any form.

\section{Funding:}

The authors didn't have any financial support. This research did not receive any specific grant from funding agencies in the public, commercial, or not-for-profit sectors. This research is a part of requirements for obtaining Ph.D. degree.

\section{Acknowledgements:}

This work was carried out inside Egyptian Drug Authority (EDA), National Organization for Drug Control and Research (NODCAR), Microbiology Department, Division of Basic Medical Science.

\section{Author Contributions:}

ALH designed the experiments, carried out the study, interpreted the data and drafted the manuscript. TRE carried out the molecular identification and phylogenic analysis of cyanobacteria isolates.

MWS, HMH and HAG supervised all experiments and reviewed the manuscript.

Conflict of interest: The authors declare that they have no conflict of interest for this study. 


\section{Authors' information:}

*Correspondence: email address: amira.lotfy.hanna@post.agr.cu.edu.eg; Tel.:(02-01224660996); ORCID ID: https://orcid.org/0000-0003-3983-1234.

email address: Prof_hayam_hamouda@yahoo.com; Tel.:(02-01223298183).

email address: hanan.goda@agr.cu.edu.eg; Tel.:(02-01006196987); ORCID ID: https://orcid.org/0000-00033155-0358.

email address: tarek.ragab @agr.cu.edu.eg; Tel.:(02-01124007357); ORCID ID: https://orcid.org/0000-0002$1272-6453$

email address: mahmoudsadikus63@gmail.com; Tel.:(02-01002557225); ORCID ID: https://orcid.org/00000001-7825-9790. 


\section{References}

AL-Katib, M., AL-Shahri, Y., \& AL-Niemi, A. (2015). Biosynthesis of Silver Nanoparticles by Cyanobacterium Gloeocapsa sp. International Journal of Enhanced Research in Science, Technology \& Engineering. 4(9), 115-135. http://doi.wiley.com/10.1002/9781118958308.ch9.

Beyth, N., Yudovin-Farber, I., Perez-Davidi, M., Domb, A. J. and Weiss, E. I. (2010). Polyethyleneimine nanoparticles incorporated into resin composite cause cell death and trigger biofilm stress in vivo. Proc. Natl. Acad. Sci. 107(51), 22038-22043.

Choi, O., Deng, K. K., Kim, N. J., Ross, L., Surampalli, R. Y. and Hu, Z. (2008). The inhibitory effects of silver nanoparticles, silver ions, and silver chloride colloids on microbial growth. Water Res. 42(12), 3066-3074.

Dehkordi, S. H., Hosseinpour, F., \& Kahrizang, A. E. (2011). An in vitro evaluation of antibacterial effect of silver nanoparticles on Staphylococcus aureus isolated from bovine subclinical mastitis. African Journal of Biotechnology. 10(52), 10795- 10797.

Glinel, K., Thebault, P., Humblot, V., Pradier, C. M., and Jouenne, T. (2012). Antibacterial surfaces developed from bio-inspired approaches. Acta Biomaterialia, 8, 1670e1684.

Govindaraju, K., Kiruthiga, V., Kumar, V. G., \& Singaravelu, G. (2009). Extracellular synthesis of silver nanoparticles by a marine alga, Sargassum wightii grevilli and their Antibacterial effects. Journal of Nanoscience and Nanotechnology. 9 (9), 5497-5501. https://doi.org/10.1166/jnn.2009.1199.

Gowramma, B., Keerthi, U., Rafi, M., \& Muralidhara Rao, D. (2015). Biogenic silver nanoparticles production and characterization from native stain of Corynebacterium species and its antimicrobial activity. 3 Biotech. 5 (2), 195-201. https://doi.org/10.1007/s13205-014-0210-4.

Hamida, R. S., Abdelmeguid, N. E., Ali, M. A., Bin-Meferij, M. M., \& Khalil, M. I. (2020). Synthesis of Silver Nano Using a Novel Cyano Desertifilum, Antibacterial and Cytotoxicity Effects, 15 International Journal of Nanomedicine Int. J. Nanomedicine. https://doi.org/10.2147/IJN.S238575.

Hamouda, R. A., Hussein, M. H., Abo-elmagd, R. A. and Bawazir, S. S. (2019). Synthesis and biological characterization of silver nanoparticles derived from the cyanobacterium Oscillatoria limnetica. Scientific Reports. 9:13071 | https://doi.org/10.1038/s41598-019-49444-y.

Hamouda, R. A., Al-Saman, M. A., El-Sabbagh, S. M., C, G. W. A. E.-S., \& Hendawy, A. N. (2017). Approach to improve bioactive compounds of cyano Anabaena oryzae using factorial design.

Ivask, A., Kurvet, I., Kasemets, K., Blinova,I., Aruoja, V., Suppi, S., Vija, H., Kakinen, A., Titma, T., Heinlaan, M., Visnapuu, M., Koller, D., Kisand, V. and Kahru, A. (2014). Size-dependent toxicity of silver nanoparticles to bacteria, yeast, algae, crustaceans and mammalian cells in vitro, PLoS ONE 9 (7) e102108, doi:http://dx.doi. org/10.1371/journal.pone.0102108.

Jena, J., Pradhan, N., Prasad Dash, B., Behari Sukla, L., \& kumar Panda Affiliations, P. (2013). Biosynthesis and characterization of silver nanoparticles using microalga Chlorococcum humicola and its antibacterial activity. International Journal of Nanomaterials and Biostructures, 3(1), 1-8.

Kashyap, M., Samadhiya, K., Ghosh, A., Anand, V., Shirage, P. M., \& Bala, K. (2019). Screening of microalgae for biosynthesis and optimization of $\mathrm{Ag} / \mathrm{AgCl}$ nano hybrids having antibacterial effect. RSC Advances, 9(44), 25583-25591. https://doi.org/10.1039/c9ra04451e.

Kathiraven, T., Sundaramanickam, A., Shanmugam, N., \& Balasubramanian, T. (2014). Green synthesis of silver nanoparticles using marine algae Caulerpa racemosa and their antibacterial activity against some human pathogens. Appl Nanosci, September 2017, 5:499-504.

Keskin, N. O. S., Kiliç, N. K., Dönmez, G., \& Tekinay, T. (2016). Green synthesis of silver nanoparticles using cyanobacteria and evaluation of their photocatalytic and antimicrobial activity. $\begin{array}{llll}\text { Journal of Nano } & \text { Research, } & \text { 120-127. }\end{array}$ https://doi.org/10.4028/www.scientific.net/JNanoR.40.120. 
Khan, M. J., Shameli, K., Sazili, A. Q., Selamat, J., \& Kumari, S. (2019). Rapid green synthesis and characterization of silver nanoparticles arbitrated by curcumin in an alkaline medium. Molecules, 24(4). https://doi.org/10.3390/molecules24040719.

Koo, H., Mojib, N., Hakim, J., Hawes, I., Tanabe, Y., Andersen, D., Bej, A., \& Sweetlove, M. (2019). Bacteria (16S) in growth laminae of a large conical mats from Lake Untersee, East Antarctic. SCAR Microbial Antarctic Resource System, Version 1.

Kumar, D., Kaštánek, P., and Adhikary, S. P. (2018). Exopolysaccharides from cyanobacteria and microalgae and their commercial application. Current Science. 115 (2): 234 - 241.

Kumar, G., Karthik, L., \& Bhaskara Rao, K. V. (2010). Antibacterial activity of aqueous extract of Calotropis gigantea leaves - An in vitro study. International Journal of Pharmaceutical Sciences Review and Research, 4(2), 141-144.

Li, S., Zhang, T., Tang, R., Qiu, H., Wang, C. and Zhou, Z. (2015). Solvothermal synthesis and characterization of monodisperse superparamagnetic iron oxide nanoparticles. J. Magn. Magn. Mater. 379: $226-231$.

Li, X., Xu, H., Chen, Z. and Chen, G. (2011). Biosynthesis of nanoparticles by microorganisms and their applications. Journal of Nanomaterials. doi:10.1155/2011/270974.

Magudapathy, P., Gangopadhyay, P., Panigrahi, B. K., Nair, K. G. M., \& Dhara, S. (2001). Electrical transport studies of Ag nanoclusters embedded in glass matrix. Physica. B. 299, 142-146.

Mahamuni, P. P., Patil, P. M., Dhanavade, M. J., \& Badiger, M. V. (2019). Synthesis and characterization of zinc oxide nanoparticles by using polyol chemistry for their antimicrobial and antibiofilm activity. Biochemistry and Biophysics Reports, 17(November 2018), 71-80. https://doi.org/10.1016/j.bbrep.2018.11.007.

Mahdieh, M., Zolanvari, A., Azimee, A. S., \& Mahdieh, M. (2012). Green biosynthesis of silver nanoparticles by Spirulina platensis. Scientia Iranica, 19(3), 926-929. https://doi.org/10.1016/j.scient.2012.01.010.

Mahiuddin, M. D., Saha, P. and Ochiai, B. (2020). Green synthesis and catalytic activity of silver nanoparticles based on Piper chaba stem extracts. Nanomaterials. 10, 1777; doi:10.3390/nano10091777.

Malhotra, A., Dolma, K., Kaur, N., Rathore, Y., Mayilraj, S. and Choudhury, A. (2013). Biosynthesis of gold and silver nanoparticles using a novel marine strain of Stenotrophomonas. Bioresour. Technol., 142: 727-731.

Mehta, B. K., Chhajlani, M. and Shrivastava, B. D. (2017). Green synthesis of silver nanoparticles and their characterization by XRD. IOP Conf. Series: Journal of Physics: Conf. Series 836 (2017) 012050. doi :10.1088/1742-6596/836/1/012050

Ninganagouda, S., Rathod, V., Singh, D., Hiremath, J., Singh, A. K., Mathew, J., Manzoor ul-Haq (2014). Growth kinetics and mechanistic action of reactive oxygen species released by silver nanoparticles from Aspergillus niger on of reactive oxygen species. J. Phys. Chem. B 112 (43): 13608 - 13619.

Otari, S. V., Patil, R. M., Ghosh, S. J., Thorat, N. D., \& Pawar, S. H. (2015). Intracellular synthesis of silver nanoparticle by actinobacteria and its antimicrobial activity. Spectrochimica Acta Part A: Molecular and Biomolecular Spectroscopy.

Patel, V., Berthold, D., Puranik, P., \& Gantar, M. (2015). Screening of cyanobacteria and microalgae for their ability to synthesize silver nanoparticles with antibacterial activity. Biotechnology Reports, 5(1), 112-119. https://doi.org/10.1016/j.btre.2014.12.001.

Raffi, M., Hussain, F., Bhatti, T. M., Akhter, J. I., Hameed, A., \& Hasan, M. M. (2008). Antibacterial characterization of silver nanoparticles against E. coli ATCC-15224. Journal of Materials Science and Technology,Vol.24, No.2,Pp. 192-196. 
Rajeshkumar, S., Malarkodi, C., Paulkumar, K., Vanaja, M., Gnanajobitha, G., \& Annadurai, G. (2014). Algae Mediated Green Fabrication of Silver Nanoparticles and Examination of Its Antifungal Activity against Clinical Pathogens. International Journal of Metals, 2014, 1-8. https://doi.org/10.1155/2014/692643.

Rashed, S. Al, Shehri, S. Al, \& Moubayed, N. M. S. (2018). Extracellular biosynthesis of silver nanoparticles from Cyanobacteria. Biomedical Research (India), 29(13), 2859-2862. https://doi.org/10.4066/biomedicalresearch.29-17-3209.

Rippka, R., Deruelles, J., Waterbury, J. b, Herdman, M., \& Stanier, R. (1979). Generic Assignments, Strain Histories and Properties of Pure Cultures of Cyanobacteria. Journal of General MicrobioZogy, 111, 1-61. Printed, 110(2), 1-61.

Sadowski, Z. (2010). Biosynthesis and Application of Silver and Gold Nanoparticles. Silver Nanoparticles, 257-277. https://doi.org/10.5772/8508.

Saifuddin, N., Wong, C., \& Yasumira, A. N. (2009). Rapid biosynthesis of silver nanoparticles using culture supernatant of bacteria with microwave irradiation. E-J Chem 6:61-70.

Saitou, N., \& Nei, M. (1987). The neighbor-joining method: A new method for reconstructing phylogenetic trees. Molecular Biology and Evolution4:406-425.

Singh, G., Babele, P. K., Shahi, S. K., Sinha, R. P., Tyagi, M. B., \& Kumar, A. (2014). Green synthesis of silver nanoparticles using cell extracts of Anabaena doliolum and screening of its antibacterial and antitumor activity. Journal of Microbiology and Biotechnology, 24(10), 1354-1367. https://doi.org/10.4014/jmb.1405.05003.

Sun, Y., Atorngitjawat, P., \& Meziani, M. (2001). Preparation of silver nanoparticles via rapid expansion of water in carbon dioxide microemulsion into reductant solution. Langmuir 17:57075710.

Tamura, K., Nei, M., \& Kumar, S. (2004). Prospects for inferring very large phylogenies by using the neighbor-joining method.No Title. 101:11030-11035., Proceedings of the National Academy of Sciences (USA).

Waterbury, J. B. (2006). The Cyanobacteria-Isolation, Purification and Identification, DOI: 10.1007/0-387-30744-3_38, CHAPTER 2.1). Prokaryotes (2006) 4:1053-1073.

Zak, K., Ebrahimizadeh, M., Abd-Majid, W. and Yousefi, S. (2011). Effects of annealing temperature on some structural and optical properties of $\mathrm{ZnO}$ nanoparticles prepared by a modified sol-gel combustion method. Ceram. Int. 37: 393 - 398. 